\title{
Production and Investigation of Biodiesel Fuels from Spent Coffee Grounds
}

\author{
Zilya Mustafa, ${ }^{1{ }^{*}}$, Dobromir Yordanov² and Rumyana Milina ${ }^{1}$ \\ ${ }^{1}$ Central Research Laboratory, University "Prof. Assen Zlatarov", Bourgas 8010, Bulgaria \\ ${ }^{2}$ Department of Industrial Technologies and Management, University "Prof. Assen Zlatarov", Bourgas 8010, \\ Bulgaria
}

\begin{abstract}
The oil fractions, extracted under different conditions from spent coffee grounds, were used to produce biodiesel fuels and investigate their FAME profiles. For producing of fuels, esterification and transesterification of oils with homogeneous catalysts were applied. Investigation of the esters composition (FAME) in biodiesel is carried out by modified gas chromatographic method EN 14103. The content of each individual ester was calculated using the method of internal standard. The results of total and individual FAME content in all studied objects are shown. The results show the feedstocks and extraction conditions (catalysts, temperatures) for obtaining the biodiesel with high yield and balanced composition.
\end{abstract}

Keywords: Coffee oil, spent coffee grounds, microwave irradiation, biodiesel feedstock, fatty acid methyl esters, gas chromatography.

\section{INTRODUCTION}

Biodiesel is defined as a fuel comprised of monoalkyl esters of long - chain fatty acids derived from vegetable oils, (sunflower, rapeseed, soy, palm), animal fats, waste cooking oil, algae and waste organic materials [1,2]. The resulting esters represent an excellent fuel for existing diesel engines. The benefits of biodiesel as fuel have been extensively studied and described in a large number of scientific papers.

Atadashi [3], Gerpen [4], and others authors [5] point out that using the biodiesel reduces greenhouse gas emissions in the atmosphere. Biodiesel is biodegradable, ready availability, non-toxic, nonflammable, environmentally friendly, contains no sulfur and aromatic compounds, so the exhaust emissions do not contain sulfur oxides and the total hydrocarbon content in them is $93 \%$ lower than in emissions of petroleum diesel [6]. Biodiesel has a higher cetane number (about 60 to 65) than diesel oil (53) and contains $10-11 \%$ oxygen, which contributes to its better burning [7]. It has good lubricating properties, it reduces corrosion and wear and increases overall engine efficiency [8]. Biodiesel can be successfully used in blends with petroleum diesel up to $20 \%$ (B20) without engine modifications. There is a higher ignition temperature, making it safe to transport and store [9, 10]. One of the main advantages of the biodiesel is that it reduces dependence on imported oil as local inputs

*Address correspondence to this author at the Central Research Laboratory, University "Prof. Assen Zlatarov“, Bourgas 8010, Bulgaria;

Tel: +359 888678 937; E-mail: zmustafa@abv.bg used for its production. The production of the biodiesel supports rural development because it has a good potential for employment.

The feedstocks for biodiesel production determine its properties. The two main biodiesel quality standards are ASTM D6751 [11] in the US and Canada and EN 14214 in Europe, developed by the European Committee for Standardization [12].

In the search for cheaper feedstocks in recent years, research on the use of waste from industry, agriculture and forestry and households has become more and more important: industrial wastes, mostly obtaining from waste water treatment [13], active sludge [14], waste fish oil [15,16], tall oil from the paper pulping process [17-19], spent coffee grounds [20-22], citrus seeds from orange juice production [23] and other wastes. Thus, the cost of these feedstocks is at present significantly lower than that of the edible and non-edible oils.

Coffee is one of the world's most widely consumed beverages. Spent coffee grounds (SCGs) are the main coffee industry residues. The biodiesel from spent coffee grounds possesses better stability than biodiesel from other sources due to its high antioxidant content $[21,24]$. Statistical average annual consumption in Bulgaria is about 17-18 million kilograms of coffee. This would generate almost the same amount of SCG as a valuable cheap resource for extracted oil components to be processed into biodiesel fuel.

The scientific literature provides data on the compositional profile of biodiesel obtained from oil 
fractions extracted from SCGs. It can be seen that esters of palmitic (C16: 0$)$, stearic (18: 0$)$, oleic (C18: 1), linoleic (C18: 2), linolenic (C18:3) acids are predominant [25-30]. The amount of saturated and unsaturated acids is almost the same, with a slight excess of saturated acids.

Biodiesel properties with a similar FAME profile meet the standard specifications $[25,30]$.

The aim of this study is to produce and investigate FAME profiles of biodiesel fuels from spent coffee grounds. In the course of the study, the conditions for obtaining high yield oil and biodiesel with balanced composition have been established.

\section{EXPERIMENTAL PROCEDURES}

\subsection{Materials and Standards}

The organic solvents n-hexane and methanol with analytical grade were obtained from Sigma-Aldrich (Switzerland). The reagents employed were anhydrous sodium sulfate $\left(\mathrm{Na}_{2} \mathrm{SO}_{4}\right)$ and homogeneous catalysts $\mathrm{H}_{2} \mathrm{SO}_{4}$ (sulfuric acid) and $\mathrm{NaOH}$ (sodium hydroxide).

FAME Mix C14 - C22, Fatty acid methyl esters (C14:0; C16:0; C16:1; C18:0; C18:1; C18:2; C18:3; C20:0; C20:1; C22:0; C22:1; C24:0; C24:1) and methyl heptadecanoate (C17:0) were purchased from Sigma Aldrich (Switzerland) and Supelco.

\subsection{Samples}

Residue of coffee "Bianchi" collected by vendingmachines was used for the experiments. Eleven oil fractions extracted from spent coffee grounds were used to produce biodiesel fuels applying acid-catalysed esterification and alkali-catalysed transesterification.

\subsection{Methods}

\subsubsection{Oil Extraction from Residue}

We have previously developed a method for oil extraction from spent coffee grounds [31] and applied this method in the study.

\subsubsection{Two Step Transesterification}

\section{Acid-Catalysed Esterification}

The oil fraction (up to $500 \mathrm{mg}$ ) is dissolved in hexane $(2 \mathrm{ml})$ in a test tube and $1 \%$ sulphuric acid in methanol is added. The mixture is left overnight in a stoppered tube at $50^{\circ} \mathrm{C}$ (or is refluxed for $2 \mathrm{~h}$ ), then water $(10 \mathrm{ml})$ is added and the required esters are extracted with hexane $(2 \times 5 \mathrm{ml})$, using Pasteur pipettes to separate the layers. The hexane layer is dried over anhydrous sodium sulphate. The solution is filtered and the solvent removed.

\section{Alkali-Catalysed Transesterification}

The obtained ester extract from the first step is dissolved in hexane $(1 \mathrm{ml})$ in a test-tube, $0.5 \mathrm{M}$ sodium methoxide in anhydrous methanol $(2 \mathrm{ml})$ is added, and the solution is maintained at $50^{\circ} \mathrm{C}$ for $10 \mathrm{~min}$, then water $(10 \mathrm{ml})$ is added and the required esters are extracted with hexane $(2 \times 5 \mathrm{ml})$, using Pasteur pipettes to separate the layers. The hexane layer is dried over anhydrous sodium sulfate. The solution is filtered and the solvent removed [32].

\subsection{Biodiesel Sample Preparation for GC Analysis}

Accurately weighed approximately $250 \mathrm{mg}$ of sample is placed in $10 \mathrm{ml}$ vial and $5 \mathrm{ml}$ solution of internal standard (IS) is added. The solution of IS is 10 $\mathrm{mg} / \mathrm{ml}$ methyl heptadecanoate in heptane [33]. The samples are then analyzed under the chromatographic conditions (2.5).

\subsection{GC Analysis}

GC analysis were carried out on a GC system Agilent Technologies 7890A equipped with FID, split/splitless injector and Agilent $7693 \mathrm{~A}$ automated liquid sampler. Column: HP INNOWAX, $30 \mathrm{~m} \times 0.32$ $\mathrm{mm} I \mathrm{D}, 0.25 \mu \mathrm{m}$ film thickness. Temperature program of the oven: initial temperature $210^{\circ} \mathrm{C}$ for 9 minutes, rate $20^{\circ} \mathrm{C} / \mathrm{min}$ to $230^{\circ} \mathrm{C}, 10$ minutes. Detector temperature: $300^{\circ} \mathrm{C}$, injector temperature: $250^{\circ} \mathrm{C}$. Carrier gas: $\mathrm{He}$, column flow $1.5 \mathrm{ml} / \mathrm{min}$, split ratio $1: 80$. Hydrogen flow $40 \mathrm{ml} / \mathrm{min}$, air flow $400 \mathrm{ml} / \mathrm{min}$, make-up gas (nitrogen) $40 \mathrm{ml} / \mathrm{min}$. Injection volume $1 \mu \mathrm{l}$. ChemStation for GC was used for instrument control, data acquisition and data analysis. The identification of fatty acids methyl esters was made using the standard mixture (2.1).

\section{RESULTS AND DISCUSSION}

Eleven oil extracts from spent coffee grounds (objects) were formed by a combination of factors temperature, contact time, microwave irradiation of raw material and different solvent system (Table 1). The yield and fatty acid composition of the oil fractions were investigated. The optimum conditions of the process were established by applying multi-criteria optimization techniques [31]. 
Table 1: The Experimental Design - the Eleven Objects of Optimization

\begin{tabular}{|c|c|c|}
\hline Objects & \multicolumn{2}{|c|}{$\begin{array}{c}\text { Dried at ambient conditions and microwave } \\
\text { assisted pretreatment of SCG }\end{array}$} \\
\hline \hline A & $15-20^{\circ} \mathrm{C}$ & $24 \mathrm{~h}$ \\
\hline B & $120-150^{\circ} \mathrm{C}$ & $4 \mathrm{~h}$ \\
\hline C & $450 \mathrm{~W}$ & $20 \mathrm{~min}$ \\
\hline D & $600 \mathrm{~W}$ & $20 \mathrm{~min}$ \\
\hline E & $300 \mathrm{~W}$ & $20 \mathrm{~min}$ \\
\hline F & $300 \mathrm{~W}$ & $30 \mathrm{~min}$ \\
\hline G & $450 \mathrm{~W}$ & $30 \mathrm{~min}$ \\
\hline H & $600 \mathrm{~W}$ & $30 \mathrm{~min}$ \\
\hline I & $600 \mathrm{~W}$ & $10 \mathrm{~min}$ \\
\hline J & $450 \mathrm{~W}$ & $10 \mathrm{~min}$ \\
\hline K & $300 \mathrm{~W}$ & $10 \mathrm{~min}$ \\
\hline
\end{tabular}

The oil fractions, extracted under different conditions from spent coffee grounds, were used to produce biodiesel fuels. For producing of fuels, esterification and transesterification with homogeneous catalysts were applied. Investigation of the esters composition (FAME) in biodiesel is carried out by applying a modified gas chromatographic method EN $14103[33,34]$.

Tables 2 and 3 show the contents of total and individual methyl esters in biodiesel obtained from feedstocks - oils from spent coffee grounds using $n$ hexane and $n$-hexane: methanol (1:1) as solvents. Feedstocks are marked with the same letters as objects in optimization (Table 1).

It can be seen (Table 2) that for feedstocks B, D and $E$ the total amount of esters is very low. By this indicator, the feedstock $A$ is the most suitable, since the biodiesel has the highest FAME content $(76.1 \%)$. With lower FAME content (73.6\% and $68.7 \%)$, but still high are characterized the feedstocks $\mathrm{F}$ and $\mathrm{I}$. It is also seen that the individual compositions of the feedstocks A, F and I are almost the same except for C18: 2, which is likely to result in close properties of the biodiesels obtained. The total content of esters of

Table 2: FAME Content (\%) Using $\boldsymbol{n}$-Hexane as Solvent

\begin{tabular}{|c|c|c|c|c|c|c|c|c|c|c|c|}
\hline $\begin{array}{c}\text { F } \\
\text { A } \\
\text { M } \\
\text { E }\end{array}$ & \multicolumn{11}{|c|}{ FEEDSTOCKS } \\
\hline C14:0 & 0.08 & 0.05 & 0.08 & 0.05 & 0.05 & 0.09 & 0.09 & 0.08 & 0.08 & 0.08 & 0.08 \\
\hline C16:0 & 29.8 & 19.46 & 22.30 & 16.08 & 15.98 & 28.50 & 25.50 & 20.80 & 28.10 & 26.10 & 21.40 \\
\hline C18:0 & 7.00 & 4.55 & 5.24 & 3.71 & 3.87 & 6.77 & 5.80 & 4.94 & 6.59 & 6.10 & 5.70 \\
\hline C18:1 & 8.90 & 5.89 & 7.60 & 5.06 & 5.42 & 9.24 & 7.80 & 7.39 & 7.95 & 8.30 & 9.40 \\
\hline C18:2 & 23.90 & 14.66 & 13.60 & 11.07 & 13.79 & 21.90 & 16.10 & 13.80 & 18.82 & 21.30 & 25.10 \\
\hline C18:3 & 0.36 & 0.22 & 0.19 & 0.13 & 0.20 & 0.29 & 0.20 & 0.17 & 0.27 & 0.30 & 0.41 \\
\hline C22:1 & 0.06 & 0.03 & 0.08 & - & - & 0.07 & 0.11 & 0.09 & 0.07 & 0.05 & 0.04 \\
\hline C24:0 & 0.26 & 0.18 & 0.20 & 0.14 & 0.12 & 0.25 & 0.22 & 0.21 & 0.27 & 0.23 & 0.22 \\
\hline $\mathrm{C} 24: 1$ & - & - & 0.08 & - & - & 0.06 & 0.08 & 0.07 & 0.05 & - & - \\
\hline$\Sigma_{\mathrm{s}}$ & 40.69 & 26.54 & 30.90 & 22.03 & 22.02 & 39.27 & 34.85 & 28.88 & 38.68 & 35.76 & 30.43 \\
\hline$\sum$ unsat & 33.79 & 21.12 & 22.63 & 16.78 & 19.80 & 32.18 & 25.07 & 22.50 & 28.00 & 30.44 & 35.54 \\
\hline$-\sum_{\text {mus }}$ & 9.49 & 6.24 & 8.84 & 5.58 & 5.81 & 10.01 & 8.77 & 8.53 & 8.91 & 8.89 & 10.05 \\
\hline$-\sum_{\text {pus }}$ & 24.30 & 14.88 & 13.79 & 11.20 & 13.99 & 22.17 & 16.30 & 13.97 & 19.09 & 21.55 & 25.49 \\
\hline$\sum_{\text {FAME }}$ & 76.10 & 49.03 & 56.28 & 40.00 & 42.69 & 73.59 & 61.87 & 53.58 & 68.71 & 67.86 & 67.60 \\
\hline
\end{tabular}

$\Sigma_{\mathrm{s}}$ - sum of esters of saturated fatty acids; $\sum_{\text {unsat }}-$ sum of esters of unsaturated fatty acids; $\sum_{\text {mus }}$ - sum of esters of mono unsaturated fatty acids; $\sum_{\text {pus }}$ - sum of esters of poly unsaturated fatty acids; $\sum_{\text {FAME }}$ - sum of FAME calculated by applying the gas chromatographic method EN 14103. 
Table 3: FAME Content (\%) Using $n$-Hexane: Methanol (1:1) as Solvent

\begin{tabular}{|c|c|c|c|c|c|c|c|c|c|c|c|}
\hline \multirow{2}{*}{$\begin{array}{l}\mathbf{F} \\
\mathbf{A} \\
\mathbf{M} \\
\mathrm{E}\end{array}$} & \multicolumn{11}{|c|}{ FEEDSTOCKS } \\
\hline & A & B & C & D & E & $\mathbf{F}$ & G & $\mathbf{H}$ & I & $J$ & K \\
\hline C14:0 & 0.09 & 0.07 & 0.07 & 0.07 & 0.08 & 0.09 & 0.08 & 0.06 & 0.08 & 0.07 & 0.08 \\
\hline C16:0 & 28.50 & 25.10 & 21.90 & 23.60 & 25.90 & 27.80 & 25.90 & 19.29 & 28.90 & 27.40 & 28.70 \\
\hline C16:1 & 0.19 & 0.20 & 0.20 & 0.21 & 0.20 & 0.22 & 0.20 & 0.19 & 0.22 & 0.22 & 0.20 \\
\hline C18:0 & 6.67 & 6.27 & 5.51 & 5.73 & 6.17 & 6.57 & 6.28 & 4.64 & 6.82 & 6.47 & 6.57 \\
\hline C18:1 & 8.71 & 7.69 & 7.38 & 7.38 & 8.01 & 8.33 & 8.01 & 6.16 & 8.64 & 8.51 & 8.60 \\
\hline C18:2 & 21.80 & 16.75 & 15.76 & 15.48 & 18.18 & 17.51 & 15.94 & 9.30 & 18.67 & 18.46 & 20.60 \\
\hline C18:3 & 0.32 & 0.21 & 0.22 & 0.20 & 0.24 & 0.21 & 0.18 & 0.07 & 0.24 & 0.29 & 0.29 \\
\hline $\mathrm{C} 20: 0$ & 2.88 & 2.77 & 2.53 & 2.76 & 3.12 & 2.94 & 2.92 & 2.21 & 3.13 & 2.87 & 2.79 \\
\hline $\mathrm{C} 20: 1$ & 0.34 & 0.31 & 0.70 & 0.57 & 0.47 & 0.52 & 0.55 & 0.71 & 0.67 & 0.48 & 0.40 \\
\hline $\mathrm{C} 22: 0$ & 0.52 & 0.51 & 0.60 & 0.61 & 0.58 & 0.58 & 0.62 & 0.47 & 0.65 & 0.59 & 0.53 \\
\hline $\mathrm{C} 22: 1$ & 0.06 & 0.05 & 0.05 & 0.09 & 0.06 & 0.07 & 0.09 & 0.06 & 0.03 & 0.10 & 0.08 \\
\hline $\mathrm{C} 24: 0$ & 0.22 & 0.22 & 0.23 & 0.25 & 0.24 & 0.23 & 0.25 & 0.17 & 0.26 & 0.24 & 0.21 \\
\hline $\mathrm{C} 24: 1$ & - & - & 0.04 & 0.08 & 0.05 & - & 0.05 & - & - & - & - \\
\hline$\sum_{\mathrm{s}}$ & 38.89 & 34.93 & 30.84 & 32.98 & 36.11 & 38.18 & 36.01 & 26.84 & 39.80 & 37.64 & 38.88 \\
\hline$\sum$ unsat & 31.46 & 25.21 & 24.35 & 24.01 & 27.21 & 26.86 & 24.99 & 16.49 & 28.47 & 28.06 & 30.17 \\
\hline$-\sum_{\text {mus }}$ & 9.30 & 8.25 & 8.37 & 8.33 & 8.79 & 9.14 & 8.90 & 7.12 & 9.56 & 9.31 & 9.28 \\
\hline$-\sum_{\text {pus }}$ & 22.16 & 16.96 & 15.98 & 15.68 & 18.42 & 17.72 & 16.09 & 9.37 & 18.91 & 18.75 & 20.89 \\
\hline$\sum_{\text {FAME }}$ & 72.00 & 62.00 & 58.00 & 59.00 & 65.00 & 67.00 & 63.00 & 45.00 & 70.50 & 68.28 & 71.00 \\
\hline
\end{tabular}

saturated and unsaturated acids in these objects is in the required balance.

The results in Table 3 show that feedstocks C, D and $\mathrm{H}$ are not appropriate since their biodiesel has a very low total FAME content. Again the content of esters from feedstock $A(72.0 \%)$ is the highest. A little lower is the total content of esters from feedstocks I $(70.5 \%)$. The content of individual esters and the total content of esters of saturated and unsaturated acids shows the same trends as in the previous table.

\section{CONCLUSIONS}

Spent coffee grounds were used as raw material for biodiesel production. It has been shown that coffee waste is an inexpensive and efficient biodiesel feedstock.

High yield biodiesel with balanced composition can be obtained by using oil extracted from the spent coffee grounds under the following conditions: drying at room temperature for $24 \mathrm{~h}$ and microwave radiation power of $600 \mathrm{~W}$ for $10 \mathrm{~min}$.

Highest total FAME content is obtained by transesterification of oil from SCG, when the residue was dried at room temperature for $24 \mathrm{~h}$ and the extraction is carried out with n-hexane. A little lower, but also high is the ester content of this feedstock by using $n$-hexane: methanol $(1: 1)$ as solvent.

When SCG is microwave treated, highest total FAME content is obtained at microwave radiation power of $600 \mathrm{~W}$ for $10 \mathrm{~min}$ using $n$-hexane: methanol $(1: 1)$ as solvent. A little lower, but also high is the ester content of this feedstock by using $n$-hexane.

The lower content of esters in the biodiesel from microwave treated SCG is successfully compensated by a much shorter pretreatment time $-24 \mathrm{~h}$ versus 10 $\min$.

The total content of esters of saturated and unsaturated acids and distribution of individual esters in the biodiesel from both types of feedstocks is similar and it can be expected that the resulting biodiesel will have similar properties.

\section{REFERENCES}

[1] Balat M. Potential alternatives to edible oils for biodiese production - A review of current work. Energy Convers Manag 2011; 52: 1479-92.

https://doi.org/10.1016/j.enconman.2010.10.011

[2] Sanford SD, White JM, Shah PS, Wee C, Valverde MA Meier GR. Feedstock and biodiesel characteristics report. Renewable Energy Group 2010. 
[3] Atadashi IM, Aroua MK, Aziz AA. High quality biodiesel and its diesel engine application: A review. Renew Sust Energ Rev 2010; 14: 1999-2008. https://doi.org/10.1016/j.rser.2010.03.020

[4] Gerpen JV. Biodiesel processing and production. Fuel Process Technol 2005; 86: 1097-1107. https://doi.org/10.1016/j.fuproc.2004.11.005

[5] Moser BR, Vaughn SF. Evaluation of alkyl esters from Camelina sativa oil as biodiesel and as blend components in ultra low-sulfur diesel fuel. Bioresour Technol 2010; 101: 646-53.

https://doi.org/10.1016/j.biortech.2009.08.054

[6] Balat $\mathrm{M}$, Balat $\mathrm{H}$. Progress in biodiesel processing. Appl Energ 2010; 87: 1815-35. https://doi.org/10.1016/j.apenergy.2010.01.012

[7] Sharma YC, Singh B, Upadhyay SN. Advancements in development and characterization of biodiesel: A review. Fuel 2008; 87: 2355-73 https://doi.org/10.1016/j.fuel.2008.01.014

[8] Yusuf NNAN, Kamarudin SK, Yaakub Z. Overview on the current trends in biodiesel production. Energy Convers Manag 2011; 52: 2741-51.

https://doi.org/10.1016/j.enconman.2010.12.004

[9] Atabani AE, Silitonga AS, Ong $\mathrm{HC}$, et al. Non-edible vegetable oils: A critical evaluation of oil extraction, fatty acid compositions, biodiesel production, characteristics, engine performance and emissions production. Renew Sust Energ Rev 2013; 18: 211-45. https://doi.org/10.1016/j.rser.2012.10.013

[10] Shahid EM, Jamal Y. Production of biodiesel: a technical review. Renew Sust Energ Rev 2011; 15: 4732-45. https://doi.org/10.1016/j.rser.2011.07.079

[11] ASTM Standard specification for biodiesel fuel (B100) blend stock for distillate fuels. In: Annual Book of ASTM Standards, ASTM International, West Conshohocken, Method D675108; 2008.

[12] Committee for Standardization Automotive fuels - fatty acid FAME (FAME) for diesel engines - requirements and test methods. European Committee for Standardization, Brussels; Method EN 14214; 2003.

[13] Canakci M, Van Gerpen J. Biodiesel production from oils and fats with high free fatty acids. Transactions of the ASAET 2001; 44:1429-36

https://doi.org/10.13031/2013.7010

[14] Revellame E, Hernandez R, French W, Holmes W, Alley E, Callahan II R. Production of biodiesel from wet activated sludge. J Chem Technol Biot 2011; 86: 61-8. https://doi.org/10.1002/jctb.2491

[15] Encinar JM, Sanchez N, Martinez G, Garcia L. Study of biodiesel production from animal fats with high free fatty acid content. Bioresource Technol 2012; 102: 10907-914.

https://doi.org/10.1016/j.biortech.2011.09.068

[16] Yahyaee R, Ghobadian B, Najafi G. Waste fish oil biodiesel as a source of renewable fuel in Iran. Sust Energ Rev 2013; 17: 312-9.

https://doi.org/10.1016/j.rser.2012.09.025

[17] White K, Lorenz N, Potts T, et al. Production of biodiesel fuel from tall oil fatty acids via high temperature methanol reaction. Fuel 2011; 90: 3193-9. https://doi.org/10.1016/j.fuel.2011.06.017

[18] Maki-Arvela P, Rozmyslowicz B, Lestari S, et al. Catalytic deoxygenation of tall oil fatty acid over palladium supported on mesoporous carbon. Energ Fuel 2011; 25: 2815-25. https://doi.org/10.1021/ef200380w
[19] Lappi HE, Alen RJ. Pyrolysis of crude tall oil-derived products. BioResources 2011; 6: 5121-38.

[20] Burton R, Fan XH, Austic G. Evaluation of two-step reaction and enzyme catalysis approaches for biodiesel production from spent coffee grounds. Int J Green Energy 2010; 7: 5306. https://doi.org/10.1080/15435075.2010.515444

[21] Al-Hamamre Z, Foerster S, Hartmann F, Kröger $M$, Kaltschmitt M. Oil extracted from spent coffee grounds as a renewable source for fatty acid methyl ester manufacturing. Fuel 2012; 96: 70-6. https://doi.org/10.1016/j.fuel.2012.01.023

[22] Calixto F, Fernandes J, Couto R, Hernandez EJ, NajdanovicVisaka V, Simoes PC. Synthesis of fatty acid methyl esters via direct transesterification with methanol/ carbon dioxide mixtures from spent coffee grounds feedstock. Green Chem 2011; 13: 1196-202. https://doi.org/10.1039/c1gc15101k

[23] Sharma M, Ganguly M. Shaddock (Citrus grandis) seed oil as an alternative feedstock for the production of biodiesel. Res $\mathrm{J}$ Chem Environ 2010; 14: 43-5.

[24] Caetano N, Silva V, Melo A, Martins A, Mata T. Spent coffee grounds for biodiesel production and other applications. Clean Techn Environ Policy 2014; 16: 1423-30. https://doi.org/10.1007/s10098-014-0773-0

[25] Haile M, Asfaw A, Asfaw N. Investigation of waste coffee ground as a potential raw material for biodiesel production. Int J Renew Energy Res 2013; 3: 854-60.

[26] Abdullah M, Bulent Koc A. Oil removal from waste coffee grounds using two-phase solvent extraction enhanced with ultrasonication. Renew Energ 2013; 50: 965-70. https://doi.org/10.1016/j.renene.2012.08.073

[27] Deligiannis A, Papazafeiropoulou A, Anastopoulos G, Zannikos F. Waste coffee grounds as an energy feedstock. Proceedings of the 3rd International CEMEPE \& SECOTOX Conference 2011; 617-22.

[28] Kondamudi N, Mohapatra SK, Misra M. Spent coffee grounds as a versatile source of green energy. J Agric Food Chem 2008, 56: 11757-60.

https://doi.org/10.1021/jf802487s

[29] Couto RM, Fernandes J, Gomes da Silva MDR, Simoes PC. Supercritical fluid extraction of lipids from spent coffee grounds. J Supercrit Fluids 2009; 51: 159-66. https://doi.org/10.1016/j.supflu.2009.09.009

[30] Vardon DR, Moser BR, Zheng W, et al. Complete utilization of spent coffee grounds to produce biodiesel, bio-oil, and biochar. ACS Sustain Chem Eng 2013; 10: 1286-94. https://doi.org/10.1021/sc400145w

[31] Yordanov D, Mustafa Z, Milina R, Tsonev Z. Multi-criteria optimization process of the oil extraction from spent coffee ground by various solvents. Oxid Commun 2016; 39: 147887.

[32] Christie W. Lipid Analysis: Isolation, separation, identification and structural analysis of lipids. Third edition. Oil Press, Bridgwater, England 2003.

[33] EN 14103: Fat and oil derivatives - Fatty Acid Methyl Esters (FAME) - Determination of ester and linolenic acid methyl ester contents.

[34] Milina R, Mustafa Z. Gas chromatographic investigations of compositional profiles of biodiesel from different origin. Petroleum \& Coal 2013; 55: 12-9. 